Technical Paper

\title{
Potentiality of Four Cool Season Grasses and Miscanthus sinensis for Feedstock in the Cool Regions of Japan
}

\author{
Kossonou Guillaume ANZOUA*1, Yasuhisa KAJIHARA*1, Yo TOMA*1, \\ Natsumi IIZUKA $* 1$ and Toshihiko YAMADA $* 1 * 2$ \\ (Received March 2, 2010)
}

\begin{abstract}
It is planned to increase plant biomass feedstock to sustain the renewable energy source, bioenergy. In cool regions such as Hokkaido which often offers a short and stressful growth season, less is known about biomass potential (BP) in plants, and generally there is a lack of data regarding a regional suitable harvesting system in feedstock. A constant supply of feedstock per month using several biomass plants would be important for establishing an all year round operating system (AYROS) in biofuel production. Two types of perennial lignocellulosic crops, four $\mathrm{C}_{3}$ grasses which adapt well to cool environments, orchardgrass (OG), reed canarygrass (RC), tall fescue (TF) and timothy (TI), referred to as cool season grasses (CSG) and $\mathrm{C}_{4}$ native grass, Miscanthus sinensis called 'susuki', were evaluated for the BP in Sapporo, Japan. CSG were sown into fertilized land in 2006, whilst M. sinensis was planted in 2007 without fertilization. Three years after planting, in 2009, regional potential across all harvesting of CSG was $9.7 \mathrm{t} \mathrm{ha}^{-1}$ year $^{-1}$. Different harvestings of CSG revealed high BP from RC and TI rather than OG and TF. RC showed BP peaks twice, in June (11 \pm $0.45 \mathrm{t} \mathrm{ha}^{-1}$ year $\left.^{-1}\right)$ and September $\left(15 \pm 1.11 \mathrm{t} \mathrm{ha}^{-1}\right.$ year $\left.^{-1}\right)$, and a single peak in July ( $15 \pm 1.99 \mathrm{t} \mathrm{ha}^{-1}$ year ${ }^{-1}$ ) for TI, indicating that RC is a two peaks type, whilst TI falls into a one peak type. For M. sinensis, the BP increased with the year and varied among accessions. In 2009, regional potential was 1,287 $\pm 343 \mathrm{~g} \mathrm{plant}^{-1}$ year ${ }^{-1}$. Accessions native to Hokkaido showed maximum BP of $827 \pm 353 \mathrm{~g} \mathrm{plant}^{-1}$ year $^{-1}$, mainly from Matsumae $\left(1,622 \pm 692 \mathrm{~g} \mathrm{plant}^{-1}\right.$ year $\left.^{-1}\right)$ and Toyoura $\left(2,174 \pm 169 \mathrm{~g} \mathrm{plant}^{-1}\right.$ year $\left.^{-1}\right)$. Accessions native to areas other than Hokkaido yielded a potential of 2,206 $\pm 388 \mathrm{~g} \mathrm{plant}^{-1}$ year ${ }^{-1}$, mainly from Shiozuka $(2,531 \pm$ $526 \mathrm{~g} \mathrm{plant}^{-1}$ year $\left.{ }^{-1}\right)$ and Akeno (2,653 $\pm 635 \mathrm{~g}$ plant $^{-1}$ year $\left.^{-1}\right)$, substantially higher than the BP of Hokkaido accessions. The BP of $M$. sinensis over two years of 9 accessions in the present study was about $36.9 \mathrm{t}$ ha $^{-1}$ year $^{-1}$, by converting biomass data of plant $\left(921.4 \mathrm{~g} \mathrm{plant}^{-1}\right.$ year $\left.^{-1}\right)$ to land area unit. The BP experiment estimates biomass feedstock is supplied with 10-15 tha-1 by harvesting TI and RC in June to September and $30 \mathrm{tha}^{-1}$ by harvesting $\mathrm{M}$. sinensis in October. This study demonstrated the feasibility and advantage of the combination of CSG and M. sinensis. The BP could be improved using mostly superior genotypes of $M$. sinensis selected from areas other than Hokkaido. The information from the present study will be available for establishing AYROS in feedstock production for biofuels such as bioethanol in cool regions such as Hokkaido.
\end{abstract}

\section{Key Words}

Cool season grasses, Miscanthus sinensis, Biomass, Feedstock, Cool environment

\section{Introduction}

Plant biomass is the major successful and promising renewable energy source that can be used to produce biofuels such as bioethanol. Generally, a cold environment limits plant growth and its yield performance. One way of achiev-

* 1 Field Science Center for Northern Biosphere, Hokkaido University

Kita 10, Nishi 11, Kita-ku, Sapporo-shi, Hokkaido 060-0811, Japan

*2 Corresponding author ing a biomass feedstock at the level that would ensure bioenergy production is by selection and/or combination agronomically of species to maximize regional potentiality. Among several sources, perennial grasses $\left(\mathrm{C}_{3}\right.$ and $\left.\mathrm{C}_{4}\right)$ are likely to contribute a majority of feedstock production rather than woody species ${ }^{1)}{ }^{3}$. These species contain lignocelluloses or hemicelluloses essential in the process of biomass conversion into bioethanol, and were shown to be 
promising during preliminary investigations into the sustainability of various non-food species entirely eligible for biomass production ${ }^{4}$. Moreover, biomass from these species is an abundant resource and cheap to produce ${ }^{5) \sim 7 \text { ). }}$ Therefore, the use of these species through their biomass is expected to increase, and will have the strong potential to play an important role in the future renewable energy.

Lignocellulosic biomass feedstock appears to be a successful key point in the concept of bioenergy because it is renewable. Unfortunately, the stock is limited since extensive biomass plantations have not been developed yet. Even though, biomass should be produced in sufficient quantities for bioenergy to be a viable alternative.

Lignocellulosic biomass, derived from $\mathrm{C}_{3}$ and $\mathrm{C}_{4}$ perennial grasses, can be readily produced, depending on the environment ${ }^{8}$. Plants belonging to these two kinds of grasses have exhibited several advantages beneficial for their cultivation: high yields, low production costs, high efficiencies of water, nutrients and radiation use ${ }^{9)}$. These grasses have been $\mathrm{ex}^{-}$ tensively and intensively evaluated ${ }^{10111}$. $\mathrm{C}_{3}$ grasses consist of most common forage plants grown in cold environments referred to as cool-season grasses (CSG), and their potential is known ${ }^{12}$. $\mathrm{C}_{4}$ grasses consist of various species including the genus Miscanthus, which has been shown to have a high potential by the intensive works using Miscanthus $\times$ giganteus ${ }^{13) \sim 16}$. Such information is limited for Miscanthus sinensis, called 'susuki', which is largely distributed in warm to cool environments in Japan, and is thought to be one of the progenitors of the natural triploid hybrid, $M . \times$ giganteus ${ }^{16)}$. Many studies have been done to examine $\mathrm{C}_{3}$ and $\mathrm{C}_{4}$ as bioenergy crops but under warm season conditions ${ }^{17}$. Though the combination of CSG with Miscanthus seems to be feasible and reliable for biomass feedstock, there has been no report on the combination in a cold environment.

Japan is a temperate country where CSG are cultivated as forage crops for the production of hay silage and grazing. Its northern part, Hokkaido, is the coldest area with a relatively large potential land for biomass production, but has the limiting factor of a cool environment with a short and stressful growth season. Nevertheless, some CSG are well adapted and used for forages and, for the most important forage grass, timothy, dry matter was almost $10 \mathrm{tha}^{-1}$ year ${ }^{-1}$ in Hokkaido ${ }^{18}$. On the other hand M. sinensis is native from all of Japan including Hokkaido. The potential of M. sinensis in semi natural grasslands in Japan is between 1.8-13 $\mathrm{t} \mathrm{ha}^{-1}$ year $^{-1}$ 19). Obviously such BP might be low if we use them as feedstock alone. Thus, it is important to combine different harvests with several crops, and there is now a lack of data regarding a regionally suit- able harvesting system of feedstock production for biofuels. A constant supply of feedstock per month using several grasses will be helpful for establishing an all year round operating system (AYROS) of biofuel production.

The purpose of this study was I) to evaluate the BP of CSG and M. sinensis, II) to establish a model for a potential feedstock for an AYROS in a cool environment with the combination of CSG and M. sinensis.

\section{Materials and Methods}

\subsection{Environment in experiment site}

The experiment was conducted in Sapporo in Hokkaido, the most northern and the coldest area of Japan. Considering the specificity of Hokkaido's environment, weather data (total rainfall and sunshine, mean daily radiation and temperature) in relation to the period of the plants' growth was provided to analyze the BP response. The data (source is Japan Meteorological Agency) concerned a long period average (1961 2007), 2008 and 2009.

\subsection{Agronomic techniques}

The field experiment was carried out over a 4-year period from 2006 to 2009 at the Experiment Farm of Field Science Center for Northern Biosphere of Hokkaido University, Sapporo, Hokkaido, Japan ( $43^{\circ} 04^{\prime}$ N, $141^{\circ} 21^{\prime}$ E), in alluvial soil. Two different perennial grasses species were evaluated for their BP: Four $\mathrm{C}_{3}$ grasses, reed canarygrass cv. "Venture"(Phalaris arundinacea L.) (RC), timothy cv. "Natsusakari”(Phleum pratensis L.) (TI), orchardgrass cv. "Toyomidori"(Dactylis glomerata L.) (OG) and tall fescue cv. "Hokuryo"(Festuca arundinacea Schreb.) (TF), here referred to as cool-season grasses (CSG), and one $\mathrm{C}_{4}$ native grass, Miscanthus sinensis Anderss, Nine accessions of $M$. sinensis were collected from different elevations in different regions of Japan. Accessions included six natives from Hokkaido, and three natives from areas other than Hokkaido. The characteristics of plants and locations are summarized in Table 1 and 2. Briefly, CSG used in this study are winter hardy, establish themselves rapidly, grow fast and are harvestable several times, but generally require high fertilization to produce high biomass yield ${ }^{20}$. In contrast, $M$. sinensis grows well in poor soil and under drought stress conditions, but establishes itself slowly, and is not tolerant to frequent cutting.

Seeds of RC (225 $\left.\mathrm{g} \mathrm{a}^{-1}\right)$, OG (150 $\left.\mathrm{g} \mathrm{a}^{-1}\right)$, TI $\left(150 \mathrm{~g} \mathrm{a}^{-1}\right)$, $\mathrm{TF}\left(150 \mathrm{~g} \mathrm{a}^{-1}\right)$ were broadcasted on August $25^{\text {th }} 2006$, in a completely randomized split-block design with four replications. The block size was $2.5 \mathrm{~m} \mathrm{x} 2.0 \mathrm{~m}$ for each CSG. The same design, but with two replications and a block size of $2.5 \mathrm{~m} \times 0.5 \mathrm{~m}$ for each accession was used as a 
Table 1 Cool season grasses used in the present study and their characteristics

\begin{tabular}{|c|c|}
\hline Cool season grasses & Characteristics \\
\hline Orchardgrass (OG) & $\begin{array}{l}\text { Perennial; fast growth } \\
\text { Earlier mature; High yield; fertilization } \\
\text { Resistance and tolerance (drought, shade, disease) }\end{array}$ \\
\hline Reed canarygrass (RC) & $\begin{array}{l}\text { Perennial; tall; leafy } \\
\text { medium and late maturity; High yield } \\
\text { Resistance and tolerance (winter hardy, wet land, diseases) }\end{array}$ \\
\hline Tall fescue (TF) & $\begin{array}{l}\text { Perennial; fast growth } \\
\text { Resistance and tolerance (drought, shade, high temperature) } \\
\text { Nutrient and water use efficiency }\end{array}$ \\
\hline Timothy (TI) & $\begin{array}{l}\text { Perennial; fast growth and establishment } \\
\text { High yield ; high fertilization; hay production } \\
\text { Resistance and tolerance (winter hardy) } \\
\text { Weakness (drought, shade, salt or alkalinity) }\end{array}$ \\
\hline
\end{tabular}

Table 2 Miscanthus sinensis accessions used in the present study and their location characteristics

\begin{tabular}{llcccccc}
\hline & & $\mathrm{RF}$ & $\mathrm{SS}$ & $\mathrm{Tp}$ & Lat & Long & Alt \\
\cline { 3 - 8 } Location & City & $\mathrm{mm}$ & $\mathrm{hr}$ & ${ }^{\circ} \mathrm{C}$ & ${ }^{\circ}$ & & $\mathrm{c}$ \\
\hline Hokkaido & Teshikaga & 839 & 1,469 & 4 & 44 & 144 & 166 \\
Hokkaido & Bihoro & 697 & 1,779 & 5 & 44 & 144 & 429 \\
Hokkaido & Otaru & 1,218 & 1,652 & 8 & 43 & 141 & 56 \\
Hokkaido & Makkari & 1,499 & 1,462 & 7 & 43 & 141 & 268 \\
Hokkaido & Toyoura & 1,198 & 1,501 & 7 & 43 & 141 & 8 \\
Hokkaido & Matsumae & 1,271 & 1,412 & 10 & 41 & 140 & 20 \\
Iwate & Morioka & 1,254 & 1,740 & 10 & 40 & 141 & 139 \\
Yamanashi & Akeno & 1,956 & 2,108 & 17 & 34 & 133 & 209 \\
Tokushima & Shiozuka & 1,191 & 2,141 & 14 & 36 & 138 & 457 \\
\hline
\end{tabular}

Mean 22 years rainfall: RF, temperature: Tp, sunshine: SS, latitude: Lat, longitude: Long, altitude: Alt.

Source: Japan Meteorological Agency.

method of space planting for $M$. sinensis. $M$. sinensis seeds were sown on $13^{\text {th }}$ March 2007 in a seed-tray $(6 \times 6$ holes $)$, and kept in a greenhouse. A single seedling was transplanted in the field on $30^{\text {th }}$ May 2007 at a density of $0.5 \mathrm{~m}$ $\times 0.5 \mathrm{~m}$. 5 plants per accession were transplanted in each block. Field management including irrigation, fertilization and/or pesticide were not applied to the $M$. sinensis field except for weeding at establishment, whilst only a compound fertilizer was applied to the CSG field at a levels of $\mathrm{N}=3.6 \mathrm{~g} \mathrm{~m}^{-2}, \mathrm{P}_{2} \mathrm{O}=6.6 \mathrm{~g} \mathrm{~m}^{-2}$ and $\mathrm{K}_{2} \mathrm{O}=6.6 \mathrm{~g} \mathrm{~m}^{-2}$ at sowing, and at levels of $\mathrm{N}=16 \mathrm{~g} \mathrm{~m}^{-2}, \mathrm{P}_{2} \mathrm{O}=22 \mathrm{~g} \mathrm{~m}^{-2}$ and $\mathrm{K}_{2} \mathrm{O}=16 \mathrm{~g}$ $\mathrm{m}^{-2}$ in the early spring of subsequent years.

\section{$2.3 \mathrm{BP}$}

The CSG field was harvested once (October) in 2007, twice (June and September) in 2008. A single cutting treatment per year was used to harvest CSG in 2009. This technique differs from the conventional system in which frequent cutting is usually required for forage or grazing. Thus, the aboveground of each CSG was harvested monthly within a sampling size of $0.1 \mathrm{~m}^{2}$ from each experiment pot from May to October in 2009, regardless of its growth stage. $\mathrm{BP}\left(\mathrm{t} \mathrm{ha} \mathrm{a}^{-1}\right)$ was estimated after oven drying at $70^{\circ} \mathrm{C}$ at a constant weight over 3 days. For $M$. sinensis, the aboveground biomass of each plant was harvested once per year manually within $0.25 \mathrm{~m}^{2}$ (one plant) in late autumn (October 21 2008 and October 26 $6^{\text {th }} 2009$ ), and weighted to determine the total fresh weight (TFW). A subsample was taken, weighted to determine the sub-sample fresh weight (SFW), oven dried as with CSG to determine the sub-sample dry weight (SDW). Then the BP was estimated as:

$$
\mathrm{BP}\left(\mathrm{g} \text { plant }^{-1}\right)=\mathrm{TFW} \times \text { ratio }[\mathrm{SDW} / \mathrm{SFW}]
$$

Where W (weight) unit was gram (g), and BP was estimated per plant (g plant $\left.{ }^{-1}\right)$. Accession BP was estimated as the average of 10 plants ( 5 plants per replication).

\subsection{Statistical analysis}

Each year's data was analyzed separately using the statistical software SPSS version PASW statistic 17.0. The Student-Newman-Keuls method for the means separation was used to show significant differences when necessary. For $M$. sinensis, the means difference and standard error were estimated using 10 plants (5 plants per replication) due to limited number of replications. 


\section{Results}

3.1 Growing period and weather conditions

The growing season of plants covers the period from April to October and the weather conditions during each period are summarized in Fig. 1. The trend of the daily temperatures remained consistent and the differences between years were slight. The temperature increased from April to July, rose higher in July and August, and then decreased thereafter. However, the mean temperature per month based on the plants' growth period, was $14.5^{\circ} \mathrm{C}, 16.2$ ${ }^{\circ} \mathrm{C}$ and $15.8^{\circ} \mathrm{C}$ for the period 1961 2007, 2008 and 2009, respectively. Environmental variation was mostly due to changes in total rainfall, sunshine duration and slightly in solar radiation for the same plants' growing period. The long period average indicated that for the later growth season, September was the most humid. It appeared that generally, 2008 and 2009 were dry, markedly pronounced in September, with remarkable humidity in July 2009. However, mean total rainfall per month was 89.9, 51.6 and 80.2 mm for 1961 2007, 2008 and 2009, respectively. Sunshine duration also was not consistent, but compared to the long period average, 2008 and 2009 had less sunshine during a large part of the growing season, markedly in July in 2009.
Mean total duration per month showed 182, 182 and 166 hours for 1961 2007, 2008 and 2009, respectively. Solar radiation however, was higher in 2008 than both 2009 and the long period average, 1961 2007. It was particularly lower in July in 2009 which was generally higher than the long average. Mean solar radiation per month showed 15, 17.9 and 15.6 $\mathrm{MJ} \mathrm{m}^{-2}$ for 1961 2007, 2008 and 2009, respectively.

\section{$3.2 \mathrm{BP}$}

\subsubsection{BP of CSG}

Fig. 2 detailed the BP of RC, TI, OG and TF based on single cutting treatment per year from May to October. The amount of the BP varied monthly and among species. Across all harvestings of CSG, total BP averaged $9.7 \mathrm{t} \mathrm{ha}^{-1}$ year $^{-1}$. RC yielded the highest average (11 t ha-1 year $^{-1}$ ) $\mathrm{BP}$ with two peaks, in June (13 t ha $\mathrm{h}^{-1}$ year $^{-1}$ ) and in September (16 t ha $\mathrm{t}^{-1}$ year $^{-1}$ ), showing almost constant BP during the growing season except for summer time due to a slight summer depression. Although the BP of TF (8.6 t ha $\mathrm{h}^{-1}$ year $^{-1}$ ) increased almost continuously, the trend was almost similar to that of RC with two peaks, in June ( $9 \mathrm{t} \mathrm{ha}^{-1}$ year ${ }^{-1}$ ) and the higher one in September (14 t ha ${ }^{-1}$ year $\left.^{-1}\right)$, but the
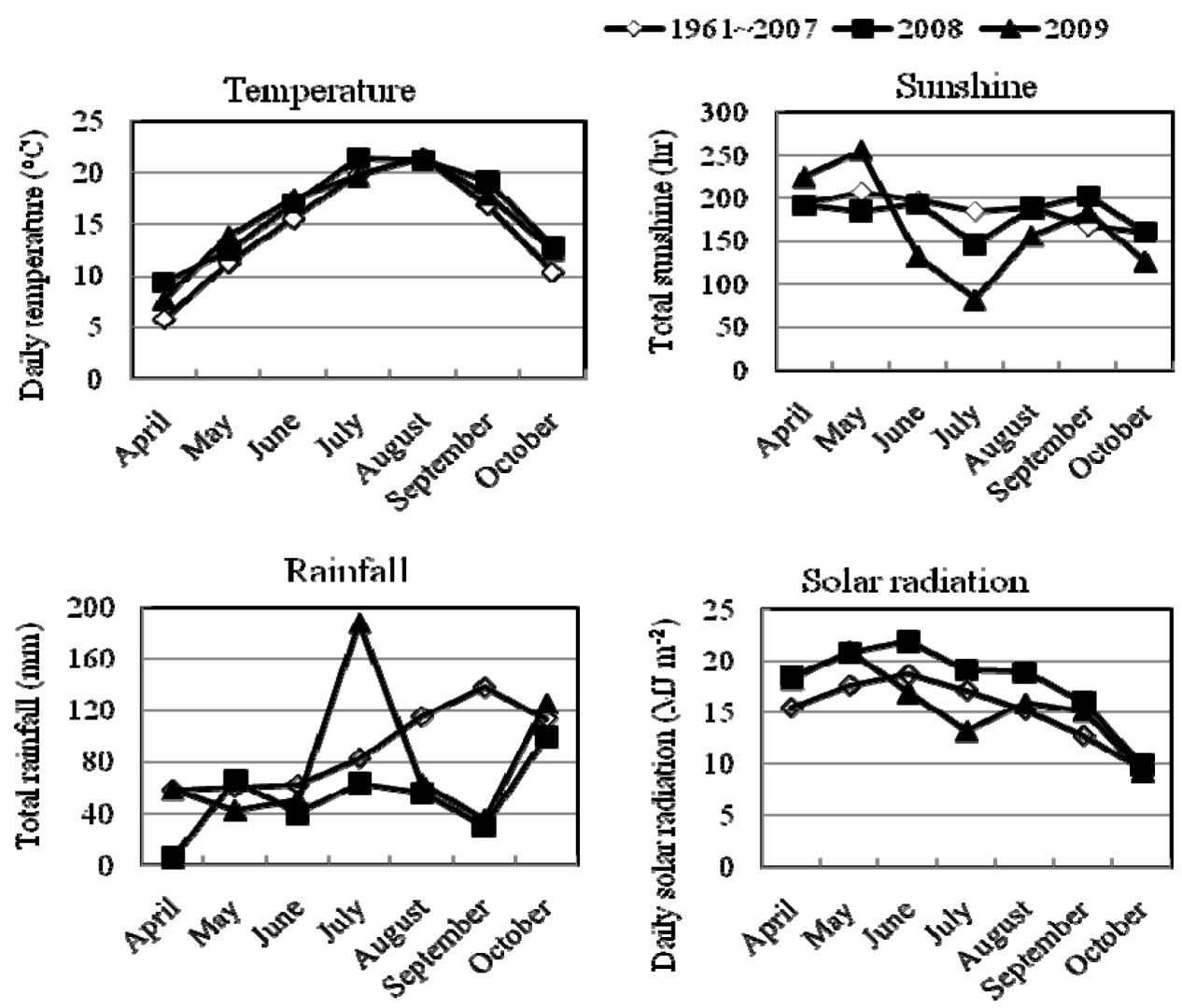

Period

Period

Fig. 1 Monthly mean of daily temperature $\left({ }^{\circ} \mathrm{C}\right)$, total rainfall $(\mathrm{mm})$, total sunshine duration $(\mathrm{hr})$ and daily solar radiation $\left(\mathrm{MJ} \mathrm{m}^{-2}\right)$ during the period of plant growth (April October) in Sapporo, Hokkaido. Data were considered for a long period (1961 2007), 2008 and 2009. Source: Japan Meteorological Agency (JMA, 2009) 


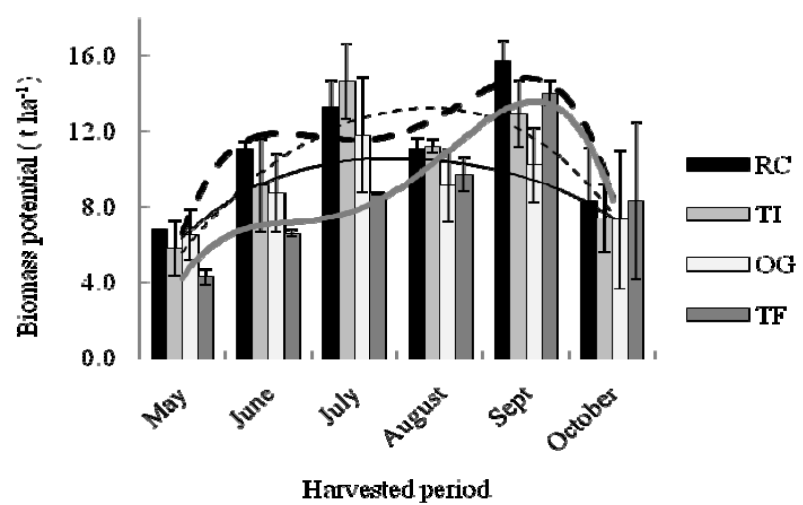

Fig. 2 Changes in biomass potential of four cool season grasses, Reed canarygrass (RC), Timothy (TI), Orchardgrass (OG), Tall fescue (TF) grown over four years $(2006 \sim 2009)$ in Sapporo, Hokkaido, by harvesting monthly in 2009. Broken thick line indicates RC; broken fine line, TI; full fine line, OG and full thick line, TF. Values represent the mean of four replications. Vertical bars indicate the standard error

yield from $\mathrm{TF}$ was quite smaller than that of RC. The BP of TI (10.2 $\mathrm{tha}^{-1}$ year $\left.^{-1}\right)$ increased to reach a single peak in July (15 $\mathrm{t} \mathrm{ha}^{-1}$ year $\left.{ }^{-1}\right)$, and decreased thereafter. OG $\left(8.9 \mathrm{tha}^{-1}\right.$ year $\left.^{-1}\right)$ also showed a similar trend to TI with a single peak in July ( $13 \mathrm{t} \mathrm{ha}^{-1}$ year $^{-1}$ ), but yielded less compared with TI. Generally, in later autumn, in October, the BP of all CSG decreased, 8.3, 7.4, 7.3 and $8.3 \mathrm{t} \mathrm{ha}^{-1}$ year $^{-1}$ for RC, TI, OG and TF, respectively.

\subsubsection{BP of Miscanthus sinensis}

The BP of $M$. sinensis accessions increased with the year, and varied significantly (P<0.001) among accessions according to the locations. Fig. 3 detailed BP of M. sinensis accessions over two years, 2008 and 2009. Across accessions, total BP average increased from $556 \pm 145 \mathrm{~g}$ plant $^{-1}$ year $^{-1}$ in 2008 to $1,287 \pm 343 \mathrm{~g} \mathrm{plant}^{-1}$ year $^{-1}$ in 2009 . In 2009 , considering only the native accessions from Hokkaido, total average of BP was $827 \pm 353 \mathrm{~g}$ plant $^{-1}$ year $^{-1}$. Accession from Toyoura $\left(2,174 \pm 169 \mathrm{~g} \mathrm{plant}^{-1}\right.$ year $\left.^{-1}\right)$ and



Fig. 3 Comparison of biomass potential ( $\mathrm{g} \mathrm{plant}^{-1}$ ) of Miscanthus sinensis accessions native to Hokkaido and from areas other than Hokkaido, grown in Sapporo, Hokkaido over three years (2007 2009), and harvested in late autumn of 2008 and 2009. The values represent the mean of 5 plants replicated twice. Vertical bars indicate the standard error
Matsumae $\left(1,622 \pm 692 \mathrm{~g} \mathrm{plant}^{-1}\right.$ year $\left.^{-1}\right)$ produced high BP. Accessions from Otaru (527 $\pm 41 \mathrm{~g} \mathrm{plant}^{-1}$ year $\left.^{-1}\right)$, Bihoro $\left(442 \pm 53 \mathrm{~g} \mathrm{plant}^{-1}\right.$ year $\left.^{-1}\right)$, Teshikaga (115 $\pm 26 \mathrm{~g} \mathrm{plant}^{-1}$ year $^{-1}$ ) and, particularly those from Makkari $(84 \pm 31 \mathrm{~g}$ plant $^{-1}$ year $^{-1}$ ) showed low potential. A similar phenomenon was observed with $M$. sinensis accessions native to areas other than Hokkaido where BP increased with the year and varied significantly $(\mathrm{P}<0.001)$ among accessions (Fig. 3). Their total BP across accessions averaged $910 \pm$ 298 in 2008 and $2,206 \pm 388 \mathrm{~g} \mathrm{plant}^{-1}$ in 2009 . In that group, the highest BP were $2,653 \pm 635 \mathrm{~g} \mathrm{plant}^{-1}$ year $^{-1}$ followed by 2,531 $\pm 562 \mathrm{~g} \mathrm{plant}^{-1}$ year $^{-1}$ in 2009 as the performances of accessions from Akeno and Shiozuka, respectively (Fig. 3), and the lowest potential was 1,434 \pm $417 \mathrm{~g}$ plant $^{-1}$ year $^{-1}$ for the accession from Morioka. Most interestingly, in 2009, these accessions native to areas other than Hokkaido and relatively warmer than Hokkaido, outyielded the accessions from Hokkaido (Fig. 4). The BP of M. sinensis in Hokkaido was about $36.9 \mathrm{t} \mathrm{ha}^{-1} \mathrm{year}^{-1}$, converting average biomass data of plant (921.4 $\mathrm{g} \mathrm{plant}^{-1}$ year ${ }^{-1}$ ) across two years and all accessions from the present study.

\section{Discussion}

This study evaluated the feasibility of the combination of perennial $\mathrm{C}_{3}$ and $\mathrm{C}_{4}$ grasses with respect to the supply of constant and high biomass feedstock within the concept of an AYROS in cool environment regions such as Hokkaido. After a few year of the plants' establishment, the $\mathrm{BP}$ highlights that both $\mathrm{C}_{3}$ and $\mathrm{C}_{4}$ grasses were able to survive through several winter seasons and produced high biomass at least until the fourth year for CSG and the third year for M. sinensis. The fact that their BP was evaluated per year for several years after planting is a common situation with perennial grasses due to their slow establishment. Then a substantial yield can be obtained, and this practice leads to the avoidance of winter damage during the first or second year of planting ${ }^{23321}$. However, it must be noted that the harvest model with a combination of CSG, known to grow fast and establish rapidly, and $M$. sinensis, known to establish slowly, showed high total regional BP in terms of biomass feedstock when several years had passed after establishment in the field.

Considering the specificity of cool environment of Hokkaido, the total regional BP level appears to be satisfactory in term of capacity and capability. However, there was a great variation in $\mathrm{BP}$ with both grasses $\left(\mathrm{C}_{3}\right.$ or $\left.\mathrm{C}_{4}\right)$. This might be associated with their genetic background. In a previous study conducted in Denmark ${ }^{22}$, interaction between accessions and year was not observed in the bio- 
mass yield of Miscanthus during the first three years after establishment. The accessions used in our study also showed similar behavior. Thus, the yearly variation may be attributable to their perennial nature; because accessions might not yet have reached their maximum growth. Considering CSG, one peak of biomass production was obtained in the middle of the growing season (July) with TI and OG. When carefully considering their trend, OG yield was lower and seemed earlier than TI as previously reported ${ }^{17}$. The short growth duration might limit biomass production and indirectly explain the difference in performance. Conversely, two peaks of biomass production were obtained in earlier (June) and later (September) in the growing season with RC and TF. However, RC performed better than TF, probably due to its vigorous morphological growth ${ }^{17}$. Thus, it can be speculated that, using a single cutting system, which differs from the conventional techniques applied to forage production, it is possible to obtain a potential feedstock from CSG in a cool environment. However, the short growth duration mostly during the growing season would limit ample feedstock. This implies that their combination with other species should be essential for the purpose of constant feedstock production.

This study also revealed a strategy to improve substantially the capacity and capability of biomass production in Hokkaido by harvesting M. sinensis. However, the performance of accessions is strongly dependant on the environmental factors of their original locations, which determines their genetic background, and results in a large variation in BP. Generally, Miscanthus is known to exhibit high potential even when grown in stressful conditions, due to their capacity to convert efficiently environmental factors into biomass production ${ }^{16) 23)}$. High productivity of $M . \times$ giganteus was reported from field experiments with a small

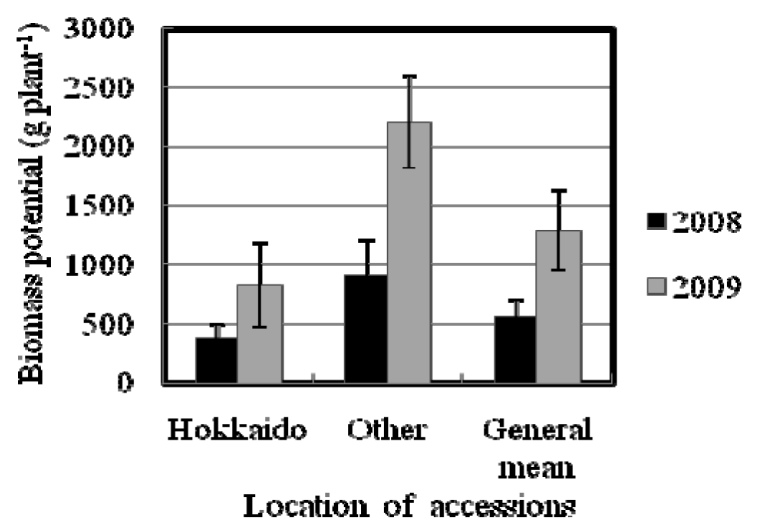

Fig. 4 Regional distribution of biomass potential (g plant ${ }^{-1}$ ) based on Miscanthus sinensis accessions grown in Sapporo Hokkaido over three years (2007 2009) and harvested in late autumn of 2008 and 2009. The values represent the mean of 5 plants replicated twice. Vertical bars indicate the standard error plot $(0.01 \mathrm{ha})^{24)}$, and a potential within a range of $25 \sim 40 \mathrm{t}$ $\mathrm{ha}^{-1}$ was also reported ${ }^{25 / 8) 26) 27}$. These potentials are close to what was observed in our study (Fig. 4) for Hokkaido (36.9 $\left.\mathrm{t} \mathrm{ha}^{-1}\right)$. But the difference was that, in our study, plot size (1.25 $\mathrm{m}^{2}$ per each accession) might have been much too small, so that BP must be considered carefully, and also the plant material used was $M$. sinensis, one progenitor of $M . \times$ giganteus ${ }^{116)}$. Anyway, this result confirms the high $\mathrm{BP}$ of Miscanthus, and delivers a satisfactory result in comparison with recent reviews ${ }^{26) 28)}$. More interestingly, $M$. sinensis accessions from other areas in the south of Japan with high altitude were tolerant to Hokkaido's cold environment. Subsequently, that behavior allows for identifying superior accessions with better and higher BP than native accessions from the Hokkaido region, which are mainly early flowering types, and which cease growth in early autumn. Thus a strategy that introduces accessions from other areas would be beneficial for increasing the BP of $M$. sinensis in Hokkaido.

In almost all cases, feedstock is the principal determinant for bioenergy production. With regard to the biomass production of CSG under the present conditions, RC and TI produced high yields with a performance similar to switchgrass, another promising bioenergy plant, largely tested in North America, under warm season conditions ${ }^{29)}$. Thus, $\mathrm{RC}$ and TI can be combined with $M$. sinensis which is harvested in late autumn. Most researches recommended the harvesting of switchgrass in early spring ${ }^{29}$. In consideration of Hokkaido's condition (high snowfall area), our study demonstrates that late autumn is a suitable harvesting time of $M$. sinensis, and the yield will be high. The cost of producing biomass depends on plant species, but it would be important to supply cheapest possible feedstock for biofuel production ${ }^{30}$. It is also known that the feedstock value depends on factors such as the conservation method ${ }^{30}$, which affects the quality and quantity of biomass. In snowy areas like Hokkaido, it is difficult to conserve plant materials of Miscanthus in the field over the winter season. Thus, it might be reasonable to use a feedstock from the harvesting of willow ${ }^{3)}$ in early spring in order to reduce the stock duration and cost of preservation.

\section{Conclusion}

Biomass feedstock is supplied with 10-15 $\mathrm{t} \mathrm{ha}^{-1}$ by harvesting $\mathrm{TI}$ and $\mathrm{RC}$ in June to September and $30 \mathrm{tha}^{-1}$ by harvesting $M$. sinensis in October. A combination of CSG with $M$. sinensis would be reliable and stable model system for total biomass feed stock. The BP could be improved using mostly superior genotypes of $M$. sinensis selected 
from areas other than Hokkaido. This model will be beneficial in establishing AYROS in feedstock production for biofuels such as bioethanol in cool regions such as Hokkaido.

\section{Acknowledgements}

This work was partially supported by the New Energy and Industrial Technology Development Organization, Japan (NEDO). The authors thank staff of Crop Group of Experiment Farm of Field Science Center for Northern Biosphere of Hokkaido University for field management.

\section{References}

1) Heaton, E. A., Clifton-Brown, J., Voigt, T. B., Jones, M. B., Long, S. P., Mitigation and Adaptation for Global Change, 9, 433 (2004)

2) EERE, Energy Efficiency Renewable Energy, www.eere.energy.gov Bulletin(2010)

3) Atkinson, C. J., Biomass and Bioenergy, 33, 752 (2009)

4) Yang, B., Wyman, C. E., Biofuels Bioprod. Bioref., 2, 26 (2008)

5) Dan, S., Yvone, S., JICE, www.alternatefuelsworld.com (2008)

6) Zhao, Y. L. Abdughani, D., Yosef, S., Wang, X., Osman, A., Guang, H. X., Field Crops Research, 111, 55 (2009)

7) Royal Society, Policy document, 1, 8(2008)

8) Clifton-Brown, J. C., Lewandowski, I., Anderso, B., Basch, G., Christian, D. G., Kjeldsen, J. B., Jorgensen, U., Mortensen, J. V., Rich, A. B., Kai-Uwe, S., Tayebi, K., Fernando, T., Agron. J., 93, 1013 (2001)

9) Dohleman, F. G., Long S. P., Plant Physiology, 150, 2104 (2009)

10) Clifton-Brown, J. C., Breuer, J., Michael B. J., Global Change Biology, 13, 2296 (2007)

11) Boe, A., Owens, V., Gonzalez-Hernandez, J., Stein, J., Lee, D. K., Koo, B. C., GCB Bioenergy, 1, 240 (2009)

12) Mantineo, M., D’Agosta, G. M., Copani, C., Cosentino, S.
L., Field Crop Research, 114, 204(2009)

13) William, F. A., Michael, D. C., Brian, S. B., In Genetic Improvement of Bioenergy Crops, (Springer), 309(2008)

14) Clifton-Brown, J. C., Jones, M. B., Breuer, J., Aspects of Applied Biology, 65, 153(2000a)

15) Clifton-Brown, J. C, Lewandowski I., New Phytologist, 148, $287(2000 b)$

16) Astley, H., Clifton-Brown, J. C., Marting, W. C., Paul, M., Pete, S., GCB Bioenergy, 1, 154(2009)

17) Kiso, S., Kikuchi K., J. Japan. Grassl. Sci., 35, 293 (1990)

18) Joseph, G. R., Biomass and Bioenergy, 34, 500 (2010)

19) Ryan, S. J., Toma, Y., Fabian, F., Aya, N., Yamada, T., Bollero, G, GCB Bioenergy, 1, 126 (2009)

20) Marving, H. H., The Pensylvania state University, Agronomy Facts, 26, (2008)

21) Hancock Seed Campany, Farmer Direct Wholesale Grass Seed, www.hancockseed.com (2008)

22) Hodkinson, T. R., Renvoize, S., Kew Bulletin, 56, 759 (2001)

23) Ehlke, N. J. , Undrssander D. J., Field crop Manual, www.hort.purdue.ed/NEWCROP/AFCM/grasseed (2000)

24) Jorgensen, U., Biomass and Bioenergy, 12, 155(1997)

25) Clifton-Brown J. C., Lewandowski I., Agron. J., 93, 1013 (2001)

26) Heaton, E. A., Dohleman, F. G., Long, S. P., Global Change Biology, 14, 2000 (2008)

27) Lewandowski, I., Clifton-Brown, J. C., Anderson, B., Bash, G., Christian, D. G., Jorgensen, U., Jones, M. B., Riche, A. B., Shwarz, K., Tayebi, K., Teixeran, F., Agron. J, 95, 1274 (2003)

28) Yamada, T., Japan.J. Grassl. Sci., 56, 263(2009)

29) Paul, R. A., Matt, A. S., Akwasi, A. B., Paul, W., HansJoachim, G. J., Agron. J., 98, 1518 (2006)

30) Beale, C. V., Long, S. P., Biomass and Bioenergy, 12, 6419 (1997) 